\title{
THE CASE FOR AN ANALYTICAL CONSTRUCTION AND ENFORCEMENT OF DEMAND GUARANTEES IN NIGERIA
}

\author{
Kolawole Mayomi*
}

\begin{abstract}
Demand guarantees are independent collateral undertakings that secure the beneficiary against losses arising from the risk of default in an underlying contract. However, unlike in a true guarantee, the surety's liability in a demand guarantee is insulated from disputes arising on the underlying contract as it is triggered by the beneficiary's mere demand for payment, without any need to establish the principal's default in the underlying contract. A review of Nigerian law reveals a lack of clarity in the construction and enforcement of demand guarantees, such that the courts have largely adopted a blanket approach which erroneously conflates the principles that undergird true guarantees and demand guarantees, and treats the payment obligation arising in both categories of guarantee contracts as the same. The consequence of this approach is to (a) open up the surety in a true guarantee to a primary liability; or (b) impose an onerous obligation upon the beneficiary in a demand guarantee to establish default in an underlying contract before the undertaking may be enforced. This article discusses the need for an analytical approach to the construction and enforcement of demand guarantees in Nigeria. It examines the key normative strengths of this approach which includes the 'pay now, argue later' rule, and proposes practical legal reforms through which the analytical approach could be better recognized by Nigerian courts and in Nigerian laws.
\end{abstract}

Keywords: Demand guarantees, collateral, security, Nigeria

DOI: http://dx.doi.org/10.4314/jsdlp.v7i2.11

\section{INTRODUCTION}

Commercial default undertakings fall into two broad classes: guarantees

* Partner, Disputes Resolution; S.P.A. Ajibade \& Co, Lagos, Nigeria. Email: kmayomi@spaajibade.com 
and indemnities. ${ }^{1}$ A guarantee is, generally, a surety's promise to a contract obligor (the beneficiary) that in the event that the contract obligee (the principal) fails to meet a specified obligation; the surety would answer for the default, usually by payment of a stated sum. ${ }^{2}$ On the other hand, an Indemnity is a surety's promise to reimburse any loss said to be suffered by the beneficiary by reason of its dealings with the principal. ${ }^{3}$ Thus, a contract of guarantee is considered to be a secondary obligation because the surety's liability is contingent upon establishing the principal's breach of an obligation owed to the beneficiary under an underlying contract, while an indemnity contract is regarded as a primary obligation since the surety assumes immediate liability upon the beneficiary's allegation of loss. ${ }^{4}$

A demand guarantee is a stringent form of an indemnity contract. Here, a commercial surety assumes unconditional financial payment obligations as security for the fulfillment of the principal's contractual obligations in an underlying contract. The demand guarantee is regarded as an 'autonomous' contract as the payment obligation contained therein is triggered by the beneficiary's demand, which complies with the terms of the guarantee contract, and does not require proof of the principal's default under the underlying contract. ${ }^{5}$

Considering that the ordinary contract of guarantee and the demand guarantee share generic grouping as commercial default undertakings, it is common to find the label 'guarantee' loosely used to describe an obligation, which is, in reality, an indemnity, and vice-versa. However, considering the summary payment obligation which attaches to demand guarantees, a proper construction of the undertaking comes to the fore as the classification of an undertaking would have a significant bearing on the extent and nature of the surety's liability. This article focuses on the construction of demand guarantee contracts in Nigeria. The two approaches to the construction of demand guarantees by the Nigerian courts are examined, and the case is made for the lesser-used analytical

1 Geraldine Andrews and Richard Millett, Law of Guarantees (6th edn, Sweet \& Maxwell 2011) 2.

2 Jelili, Omotola, Law of Secured Credit (2nd edn, Evans Brothers Ltd 2006) 10.

3 Peter Tiwell (Nig) Ltd v. Inland Bank (Nig.) Ltd [1997] 3 NWLR (Pt. 496) 408, 420.

4 Andrews and Millett(n 1) 5; Majekodunmi v African International Bank [2012] 2 BFLR 242.

5 David Warne and Nicholas Elliot, Banking Litigation (2nd ed., Sweet \& Maxwell 2005), 273. 
approach, which construes a demand guarantee as a speedy monetary remedy arising from a surety's unconditional undertaking that money will be made available to the beneficiary, upon mere demand, in the event of a perceived breach of the underlying contract; rather than the true guarantee approach which requires that an obligor's default in the underlying contract be established before the demand guarantee may be enforced. The error of the latter approach is accentuated by Nigeria's loose appellate jurisdiction, which allows the filing of interlocutory appeals to tie up contractual disputes and, by implication, allow the avoidance of a payment obligation for several years. But, this is part of the risks that a demand guarantee was required to secure, in the first place.

The article is structured into six sections. This introduction is the first section. Section 2 provides an overview of the commercial nature of demand guarantees as an autonomous payment obligation. In section 3 , the foundational principles governing the construction of demand guarantees will be outlined. Section 4 discusses the two approaches to the construction of demand guarantees in the Nigerian courts, and the triumph of the retrogressive blanket approach. Section 5 makes the case for an application of the analytical approach to the construction and enforcement of demand guarantees in Nigeria; while section 6 contains our conclusion.

\section{COMMERCIAL NATURE OF DEMAND GUARANTEES}

A demand guarantee (otherwise called 'bank guarantee', or 'on-demand bond', or 'performance bonds') is a form of an indemnity contract ${ }^{6}$ issued by a bank or other commercial surety as security to cover losses arising from certain identified risks; for example, non-performance of the principal's obligations, in an underlying contract. By this contract, the bank undertakes to pay a stated sum of money to the beneficiary once a demand for payment that complies with the terms of the guarantee is made. The bank's undertaking is a primary liability that crystallizes upon the beneficiary's compliant demand, without any reference to the question of the principal's default in the underlying contract. ${ }^{7}$ This principle was recognized in the recent case of Nwosu $v$.

6 Schmitthoff, Export Trade (11th edn, Smith \& Maxwell 2007) para 12-001.

7 See Nelson Enonchong, The Independence Principle of Letters of Credit and Demand Guarantees (Oxford University Press 2011) 1. 
Zenith Bank Plc ${ }^{8}$ thus:

A banker's guarantee shall effect payment on demand by the beneficiary giving a written statement that the principal has failed to perform his obligations. Such written statement will be the sole condition for the guarantor to pay under the guarantee. The guarantor will not take additional steps to determine any facts or documents relating to the underlying contract or the very appropriateness of the claim.

Conceptually, demand guarantees evolved in response to market needs to address the risk of non-performance of contractual obligations in cross-border contracts for sales of goods, large construction contracts, and other international contracts where the consequences of exposure are quite serious, and may not be easily remedied. ${ }^{9}$ Thus, the party who will be exposed would usually seek an unconditional indemnity, which gives immediate access to cash to remedy any contractual default, without having to await a protracted judicial determination of the allegation that the supplier has committed a breach of contract and, if so, the extent of his liability in damages. ${ }^{10}$ In response to these needs, banks and other commercial sureties began to issue a specialized class of guarantees known as 'on-demand bonds' whereby if the beneficiary makes a demand which complies with the terms of the bond, the guaranteed money would 'be paid without question, and the rights and wrongs argued about later. ${ }^{11}$ The surety's 'guarantee' addresses the buyer (or client)'s concerns about the supplier's failure to meet contractual obligations by substituting the supplier's promise of performance for the promise of a 'solvent' and 'reliable paymaster'. ${ }^{12}$

8 [2015] 9 NWLR (Pt. 1464) 314, 323 [B].

9 Disputes between parties to an international contract may result in protracted and expensive cross-border legal proceedings, which are often bedevilled with jurisdiction and enforcement problems. See J. C. T. Chuah, Law of International Trade: Cross-Border Commercial Transactions (4th edn., Sweet \& Maxwell 2009) 517-519.

10 Enonchong (n 7) 1; See also State Trading Corp of India v. EDF \& FM Ltd [1981] Com. L.R. 235.

11 Gerard McMeel, 'Pay Now, Argue Later'(1999) LMCLQ 5, 6. See also Cargill International SA v. Bangladesh Sugar \& Foood Industries Corp. [1996] 4 All ER 563, 568.

12 Soproma SpA v. Marine \& Animals By-Products Corp. [1966] 1 Lloyd's Rep. 367, 385 [McNair J]. 
Moreover, it is also a 'risk-distributing device ${ }^{13}$ which allocates litigation risks and puts funds into the pocket of the beneficiary, pending the resolution of the dispute. ${ }^{14}$

In other words, in an international transaction, a demand guarantee may be used to shift the burden of litigation such as the length of the proceedings, burden of proof, risk of currency fluctuation during litigation; and, most importantly, the forum of the litigation, ${ }^{15}$ to the principal. It is important to note that notwithstanding the use of the word 'guarantee'; unless the wordings of the surety's undertaking so expressly indicate, a demand guarantee will rarely be construed as a 'guarantee' in the true legal sense, i.e., an undertaking to pay only if the obligor/principal is in default. ${ }^{16}$ In practice, a demand guarantee is worded as a surety's primary liability contract to pay a stated sum to the beneficiary, once the terms of the undertaking are satisfied. ${ }^{17}$

The Supreme Court of Nigeria in African Insurance Development Corporation v. Nigerian Liquefied Natural Gas Ltd endorsed the above approach, ${ }^{18}$ where the court stated that:

If the performance bond is an 'on demand bond', as argued by the plaintiff, the defendant's liability would follow merely on a demand for payment made in good faith without a need to prove the validity of the claim. [Emphasis added]

It must also be noted that a demand guarantee is not intended to give a windfall payment to the beneficiary. The law is settled that if

13 Michael Coleman, 'Performance Guarantee' (1990) LMCLQ 223.

14 Howard Bennett, 'Performance Bonds and the Principle of Autonomy' (1994) JBL 574, 580.

15 Chung Hsin-Hsu, 'The Independence of Demand Guarantees, Performance Bonds and Standby Letters of Credit'(2006)1(2) National Taiwan University Law Review 4.

16 Heisler v. Anglo-Dal Ltd [1954] 1 WLR 1273, 1276.

17 I. O. Smith notes that insurance companies who only charge a premium for issuing a guarantee and do not have the comfort of a counter-indemnity, are more inclined to issue a true guarantee undertaking which requires proof of default before payment. However, banks do not usually want to be drawn into disputes arising from the underlying contract, and would prefer to issue a demand guarantee as they see the undertaking as a financial service which will be provided, in so far as the client's financial position with the bank is adequate and a satisfactory counter-indemnity is provided. I. O. Smith, Nigerian Law of Secured Credit (2nd edn., Ecowatch Publications 2001) 400.

18 [2000] 4 NWLR (Pt. 653) 494, 503. 
there is a call on a bond in circumstances where the beneficiary has not suffered any material loss, or if he was being paid more than the actual loss, which he sustained, then the party who provided the bond will be entitled under the underlying contract to recover the [over] payment. ${ }^{19}$

\section{CONSTRUCTION PRINCIPLES THAT UNDERGIRD DEMAND GUARANTEES}

The construction of a demand guarantee involves construing the surety's undertaking in its factual and contractual context, having regard to its commercial purpose. 'Looking at the contract without any preconception as to what it is' approaches this task.$^{20}$ It is the substance of the surety's obligations, rather than the form of the contract, that would determine the extent of the surety's obligations. ${ }^{21}$ Thus, the fact that the surety undertaking is tagged 'Indemnity Agreement', ${ }^{22}$ or states that the surety is to be liable as 'principal debtor' ${ }^{23}$ does not necessarily turn a true guarantee obligation into a demand guarantee. This is because, in law, if an indemnity obligation is couched in terms which make it plain that it is predicated upon an underlying liability of the principal, the obligation must be construed to be a true guarantee. ${ }^{24}$ Indeed, in the African Insurance Development Corporation case, ${ }^{25}$ the Supreme Court of Nigeria was careful to stress that:

It is not the tag put on the Bond that determines the obligation incurred thereby, but rather, the contents of the Bond. The proper approach when there is dispute as to whether the obligation incurred on a bond is to pay on demand or whether the obligation incurred is that of a suretyship is to revert to the contents of the bond...

19 See Cargill Int. SA v. Bangadesh Sugar \& Food Industries Corp [1998] 1 WLR 461 (CA); Comdel Commodities v. Siporex Trade SA [1997] 1 Lloyd's Rep. 424; Uzinterimpex JSC v. Standard Bank Plc. [2008] EWCA Civ. 819.

20 Gold Coast v. Caja de Ahorros del Mediterraneo [2001] EWCA Civ. 1806, paragraphs 11 and 15 [Tuckey LJ].

21 Peter Cassidy, 'Selected Questions in the Field of Bank Guarantees' (Unpublished paper) $2<$ http://law.wustl.edu/Library/cdroms/IBL/Conarb/W23/ Cas.htm>accessed12 August 2011.

22 Stadium Finance Co Ltd v. Helm [1965] 109 SJ 471.

23 Heald $v$ O'Connor [1971] 1 WLR 497, 503.

24 Andrews and Millett (n 1) 14-15.

25 African Insurance Development Corporation (n 18) 506. 
Furthermore, Andrews and Millett ${ }^{26}$ has also suggested that in constructing a surety's obligation, the pertinent question that should be asked is: considering the wording of the undertaking, would the surety be liable irrespective of whether the principal has defaulted? If the answer is yes, then the surety's liability is primary, and the contract is a demand guarantee, and not a true guarantee.

The English case of Associated British Ports v. Ferryways $N^{27}$ is a good example of how the construction of a surety's obligations impacts on his liabilities. The central question in this case was whether a surety undertaking was a true guarantee or an indemnity (demand guarantee). This question was important because the creditor had subsequently entered into another agreement with the principal debtor, which would have had the effect of discharging the surety's liability under a true guarantee, but not under an indemnity. The surety's undertaking defined the surety's obligations by reference to the principal debtor's fulfillment of all of its 'duties, commitments and liabilities entered into and/or incurred by reason of the Agreement as and when they fall due'. The Court of Appeal held that the undertaking was a true guarantee: the surety was to 'see to it' that the debtor performed its obligations under its contract with the creditor. It would only be when the debtor could not meet its primary liability to the creditor 'as and when they fall due', that the secondary liability of the surety crystallized.

In Eboni Finance \& Securities Ltd v. Wole-Ojo Technical Services, ${ }^{28}$ a project owner acted as surety to the contractor's application for a bank loan to enable him execute the project, and wrote a letter to the bank to 'guarantee' that the proceeds of the contract will be directly remitted to the bank. In the surety's letter, it was however stated that: 'We hereby guarantee prompt payment within 30 days of delivery or completion of the job.' The contractor collected the loan, but did not deliver the job. The surety declined liability to reimburse the bank. Held, upon a proper construction of the surety's undertaking, the letter was a true guarantee, and thereby unenforceable, as the surety's promise to pay the contract sum to the bank was made conditional upon the contractor's delivery of the job, which was never done.

26 Andrews and Millett (n 1) 56-57.

27 [2009] EWCA Civ. 189; [2009] 1 Lloyd's Rep 585.

28 [1996] 7 NWLR (Pt. 461) 464, 476. 


\section{TWO APPROACHES TO THE CONSTRUCTION OF DEMAND GUARANTEES IN NIGERIA}

In Lingo (Nig.) Ltd v. Nwodo, ${ }^{29}$ the Court of Appeal defined a bank guarantee as:

A bank guarantee is a security or undertaking given by a bank in respect of a transaction in which the bank shall be bound to fulfill its undertaking on demand. It is a promise by a bank to answer for the payment of some debt, or the performance of a duty in case of the failure of another who is liable in the first instance. [Emphasis added]

The above passage characterizes the muddled approach of the Nigerian courts to the construction of demand guarantees: the court failed to make the crucial distinction between a true guarantee and a demand guarantee, and gave a blanket definition that lumped up the features of both types of surety undertakings in its definition of a bank guarantee. As noted above, a bank guarantee may be construed as a demand guarantee, payable-on-demand as a primary obligation. Alternatively, it may be a true guarantee, payable only where the default of the principal is established. But, a bank guarantee cannot stand as both, as the above passage suggests.

The Nigerian law of guarantees is essentially case law driven. ${ }^{30} \mathrm{~A}$ review of Nigerian case law over the past 30 years (i.e. 1985-date) on the subject however reveals that the law has not been properly developed such as to be a serious guide on the nature of obligations that arises from default undertakings in this part of the world. In our respectful view, the problem (as we shall shortly see) is mainly rooted in the failure of our courts to recognize the crucial distinction between a true guarantee and a demand guarantee. In many instances, the courts simply adopted the true guarantee approach of requiring proof of default in the underlying contract to the task of the construction of surety undertakings. This erroneous approach had had the retrogressive effect

29 [2004] 7 NWLR (Pt. 874) 30, 44.

30 Section 4 of the Statutes of Fraud (1677) Act and Section 2 of the Contract Law (Cap 250) of the 1959 Laws of Western Nigeria (applicable in the succeeding states), which impose a requirement that contracts of guarantees must be in writing, are the only known statutory intervention in Nigeria. 
of stifling the growth of the legal principles that separately undergird true guarantee contracts and demand guarantee contracts.

The two major approaches of the Nigerian courts to the issue of the construction of demand guarantee contracts are discussed below:

\section{The Analytical Approach}

Here, a dichotomy is recognized between demand guarantees (a form of an indemnity contract) on the one hand and true guaranteed contracts on the other hand, and the court before coming to a conclusion on the surety's liability carefully considers the exact nature of the surety's obligations in an undertaking. Unfortunately, the courts rarely adopt this approach.

In Apugo\& Sons Ltd v. African Continental Bank\& Anor, ${ }^{31}$ a bank sued a contractor to recover a loan facility that was granted on the strength of the client's indemnity letter, which unconditionally promised to remit the proceeds of the contract to the bank. The trial court construed the client's indemnity letter as a true guarantee and held that the contractor was primarily responsible for repaying the loan to the bank. The contractor appealed against this judgment and joined the client (the Ministry of Agriculture) to the appeal. The appeal was argued by the parties on the basis that the question of who; as between the contractor or the client, is primarily liable to satisfy the bank's loan, would turn on whether the client's letter was a true guarantee or an indemnity contract. In constructing the indemnity letter, the Court of Appeal held that:

It was quite manifest that the Ministry of Agriculture entered into an independent contract or security to prevent the bank from being damnified by an act, the loan granted, which the Bank did at the request of the Ministry of Agriculture, the indemnor...

This is the purpose of the indemnity: The Ministry asked the Bank to supply the Appellant with overdraft facility and it entered into an undertaking with the Bank that it would see the Bank paid. It was not a guarantee that 'if the Appellant did not pay you, we would.' That, in my view, is the fundamental distinction. Upon all the authorities, I am satisfied that the whole structure of the Exhibit

31 [1989] 1 Commercial Law Review Quarterly (published by NWLR) 87. 
A as I interpret it, is to conclude that the contract is an indemnity, and not a guarantee. In this matter of the contract of indemnity, the surety; the Ministry of Agriculture, assumed a primary liability without the principal debtor, the Appellant. [Emphasis added]

We entirely agree with the court's reasoning. Indeed, the client's indemnity was a primary obligation undertaking to cover the bank's exposure on its loan to the contractor. In the leading case of African Insurance Development Corporation v. Nigerian Liquefied Natural Gas, ${ }^{32}$ a guarantor provided a performance bond in support of a contractor's obligations on a construction project. The contractor defaulted on the project, and the client/beneficiary sued to enforce the performance bond. On appeal to the Supreme Court of Nigeria, one of the issues before the court was whether the beneficiary could summarily enforce the guarantor's undertaking without showing proof of contractor's default. While the court did not make an express reference to the Apugo case, its approach to the issue of construction of the surety's undertaking was a clear endorsement of the analytical approach:

[Performance] bonds may be classified according to the obligation undertaken by the obligee. In some cases it is, in reality, a conditional guarantee, while in others, it may be what is described as an 'on demand bond' or, as it is sometimes called a 'first demand bond'. If the performance bond is an 'on demand bond', as argued by the plaintiff, the defendant's liability would follow merely on a demand for payment made in good faith without a need to prove the validity of the claim... [Emphasis added]

In our view, the above approach is unimpeachable. A demand guarantee should be constructed on its terms: a surety's unconditional undertaking to provide funds on-demand, without requiring the beneficiary to invest time and money in proving the validity of his claim.

\section{The Blanket Approach}

In the majority of cases, the Nigerian courts adopted a blanket 'allsize-fits' principle to constructing of all forms of surety undertakings as a true guarantee contract where evidence of the principal's default must

32 [2000] 4 NWLR (Pt. 653) 494, 505-506. 
be proffered before the surety's undertaking may be enforced. In the Eboni Finance case, ${ }^{33}$ a project owner/surety wrote a 'guarantee letter' to assure the Bank that the proceeds of the contract will be directly remitted to the bank 'within 30 days of delivery or completion of the job.' The Court of Appeal, without making any attempt to ascertain the nature of the surety's obligations undertaking, construed the undertaking according to the label, and concluded that the surety's promise was a guarantee. In our respectful view, while the court was ultimately right to treat the surety undertaking as a guarantee, its conclusion was premised on a wrong reasoning.

The Supreme Court of Nigeria in Fortune International Bank Plc $v$. Pegasus Trading Office enthroned the blanket approach. ${ }^{34}$ Here, a bank undertook, on behalf of an importer, to remit the payment of the balance due on a supply contract to the exporter. The goods were supplied, but the importer failed to make payment, and the bank similarly failed to honour its undertaking. The exporter sued both the bank and the importer to recover the debt. The trial court dismissed the action against the bank, but gave judgment against the importer. The Court of Appeal, however, set aside the trial court's judgment and held both defendants jointly and severally liable. The bank appealed to the Supreme Court, and one of the issues before the court was whether the bank's undertaking could be enforced as an indemnity to settle the importer's indebtedness to the exporters. In its judgment, the court, per Uwaifo JSC, stated that:

In matters of guarantee of this nature ... either of two situations could arise. One is that the guarantor may not primarily undertake to discharge the liability but only if the principal debtor failed in his obligation. There is the other situation where a person by his undertaking makes himself the real debtor... In the first case, the principal debtor has to default before the liability of the guarantor would arise. In the second case, the principal debtor simply drops out so that the guarantor becomes solely liable. Exhibit P13 unequivocally represents this scenario. The tendency is that the law appears to have moved to the center to make the right of the creditor less conditional. The creditor is now entitled to proceed against the guarantor without or independent of the incident of the default of the principal debtor. [Emphasis added]

33 [1996] 7 NWLR (Pt. 461) 464.

34 [2004] 4 NWLR (Pt. 86) 369. 
In the first part of the above passage, the Supreme Court clearly accepted the distinction between a true guarantee and a demand guarantee. Furthermore, the court found that the bank's undertaking was a demand guarantee: 'Exhibit P13 unequivocally represents this [second] scenario.' By this finding, the court effectively settled the question of liability in this case.

However, in the second (underlined) part of the passage, Uwaifo JSC (a highly regarded jurist of his time) surprisingly stated that: 'the law appears to have moved to the centre to make the right of the creditor less conditional'. The above statement, as seen above, was made in the context of discussing both true guarantees and demand guarantees contracts, but was not carefully qualified as relating only to demand guarantees. Accordingly, this principle seemed to have conflated the distinction between true guarantees and demand guarantees. The unintended consequence of this approach is to expose the surety in a true guarantee to a primary liability such as may only be imputed in a demand guarantee.

The above statement is more surprising as, at any event, the law does not 'move' to make a new contract for the parties by making a conditional contract less conditional. It is trite law that the courts cannot make a new contract for the parties, but would merely enforce the parties' contract by interpreting the words used by the parties themselves.

In the subsequent case of Nwankwo v. Ecumenical Dev. Cooperative Society, ${ }^{35}$ the Appellants guaranteed a loan of $\$ 500,000.00$ granted by the Respondent to a company owned and operated by the Appellants. When the loan was due for repayment, the company defaulted. The Respondent invoked the guarantee agreement and demanded that the Appellants should settle the debt. Although the sureties admitted the debt, they disputed their obligation to repay the debt. Thereupon, the Respondent sought to enforce the guarantee by filing a suit under the undefended list procedure. The trial court found that no meritorious defence was disclosed in the sureties' Notice of Intention to defend the suit, and entered judgment for the Respondent. The sureties' appeals to the Court of Appeal, and the Supreme Court of Nigeria were dismissed. Our point of interest in this case relates to the court's construction of the sureties' undertaking:

35 [2007] 5 NWLR (Pt. 1027) 377. 
WE, ... hereby guarantee to you the payment on demand of all sums which are now or at any time or times hereafter may become due or owing or may be accruing or become due to you by the borrower. [Emphasis added]

The Supreme Court placed reliance on the principle espoused in the Fortune v. Pegasus case to arrive at the conclusion that the above undertaking was a 'contract of guarantee'. The court then enforced the contract on the basis of evidence that the sureties had admitted that the principal debtor took a loan from the Respondent, which loan has not been satisfied. In our view, this approach to the construction of the sureties' obligation is wrong. The court ought to have considered that the sureties' primary liability in the above undertaking arose upon a simple demand. Accordingly, the only evidence that was required related to the quantum of the debt, and not of the principal's default in making payment. Arguably, assuming that the facts of the matter were cast differently; for instance, if the sureties had not admitted the principal's indebtedness to the creditor and had contested their liability, it would have been impossible to summarily enforce the demand guarantee against the sureties.

In Chami v. United Bank for Africa, ${ }^{36}$ the surety of a bank loan executed a 'Guarantee Agreement' in the following terms:

I... the undersigned hereby guarantee to you the payment of, and undertake on demand in writing made on the undersigned ... to pay you all the sums of money which may now be due or which may hereafter become due...

Upon the debtor's default, the bank sued the surety. The case went up to the Supreme Court. Although the Supreme Court ultimately enforced the surety contract, it is regrettable that the court, once again, conditioned the enforcement of the surety's obligation by proof of the principal's default to settle his debt in the underlying contract.

In Dragetanos Construction (Nig.) Ltd v. Fab Madis Ventures Ltd, ${ }^{37}$ the retrogressive approach again resulted in a demand guarantee being construed as a contract of guarantee. In this case, the Appellant made a N10 million advance payment to mobilize the contractor in a road

36 2010] 6 NWLR (Pt. 1191) 471, 501.

37 [2011] 16 NWLR (Pt. 1273) 308, 400. 
construction contract. To cover this payment, a surety bank issued two Advance Payment Guarantees (APGs) in favour of the Appellant, in the following terms: We undertake to pay you the said [N10 million] or part thereof on your first demand confirming that the contractor has not fulfilled their contractual obligation. [Emphasis added]

The contract was not properly performed, leading to an early termination. The contractor filed a pre-emptive suit to prevent the Appellant from making a call on the APGs, but the Appellant counterclaimed to enforce the APGs. In its judgement, the trial court accepted the contractor's case, and dismissed the counter-claim. On appeal, an issue arose as to the legal nature of the APG. The contractor submitted that the APG was a contract of guarantee and that proof of default by way of obtaining an arbitral award or judgment is a condition precedent to the bank's liability on the APG. The Court of Appeal initially rejected this argument. Relying on the Fortune Bank v. Pegasus case, the court stated a muddled principle at: ${ }^{38}$

Thus, the fact that the obligations of the guarantor arise only when the principal has defaulted in his obligations to the creditor does not mean that the creditor has to demand payment from the surety. Nor does he have to commence proceedings against the principal, whether criminal or civil, unless there is an express term in the contract requiring him to do so. In addition, the liability of the guarantor becomes due and mature, immediately the debtor/borrower become unable to pay his outstanding debt. The guarantor's liability is said to have crystallized. [Emphasis added]

In our view, the above statement is patently erroneous as the demand guarantee under consideration in this case was a surety unconditional promise to pay a stated sum upon demand to the beneficiary. The bank's payment obligation crystallizes upon the beneficiary's demand, and not when the principal/debtor is found to be in default, as wrongly espoused by the court. Applying the above flawed foundation, the court, inevitably, had to seek for proof of the contractor's default in the underlying contract to justify the enforcement of the APGs. Considering the dearth of judicial pronouncements on the legal nature of APG contracts in Nigeria, it is regrettable that the 
Court of Appeal missed a rare opportunity to develop the law, building on the foundational principles that were correctly stated in the Apugo and the African Insurance Development Corporation cases.

We conclude this section with the questionable decision in Welco Industriale S.P.A. v. Nwanyanwu \& Sons Enterprises. ${ }^{39}$ Here, an exporter, Welco SPA ('Welco'), imported certain equipment to Nigeria, and in the Customs Declaration Bond furnished to the pre-shipment inspection agents, it declared that the Plaintiff was its Nigerian agent (as statutorily required under Section 1(1)(2), and 2(1) of the Pre-shipment Inspection of Imports Decree 37 of 1978), and that an agency commission of $\$ 500,000$ was payable to the Plaintiff. Subsequently, however, Welco refused to pay the said commission, saying that the Plaintiff's name was only inscribed on the Customs Declaration Bond as a matter of legal formality and that the Plaintiff did not actually render any service to it. The Plaintiff sued to recover the commission, and the key issue between the parties before the trial court was whether a contract existed between the parties. In the Customs Declaration Bond, Welco had declared that:

With this, we hereby declare under our full responsibility that on the prices in our invoice, for the above goods:

(a) That a commission of $4.4 \%$ is recognised, calculated on the F.O.B. price for the amount of US $\$ 500,000$ to the company J.I. Nwanyanwu and Sons Enterprise Nigeria Limited - 4 Milverton Avenue, P. O. Box 2667 Aba, Nigeria.

(b) Except what has been indicated in paragraph (a), no other commission, compensation, out-invoice discount will be accorded to our customer or other people.

The trial court found that the above declaration had helped Welco to satisfy the legal requirement for the issuance of a clean report of findings, and gave judgement in favour of the Plaintiff. On Welco's appeal, the Plaintiff raised the argument that the Customs Declaration Bond was an 'on-demand bond' under which Welco was bound to pay agency commission to it. Surprisingly, the Court of Appeal accepted this argument. The Court stated that:

'... A bond merely amounts to a covenant to pay a sum of money, and is adopted partly because the form is sanctioned by antiquity,

39 [2005] 32 WRN 133. 
and partly because it is sometimes more flexible than an ordinary covenant...

In A.I.D.C. v. NLNG [2000] 4 NWLR (Pt. 653)494, a performance bond was considered. In the lead judgment of Ayoola JSC, stated as follows at pages 503-504:

Performance bonds are bonds made to secure the performance of a principal contract. Such bonds may be classified according to the obligation undertaken by the obligee. In some cases it is, in reality, a conditional guarantee, while in others, it may be what is described as an 'on demand bond' or, as it is sometimes called a first demand bond'.

The procurement of the clean report of findings (Exhibit D-D3) enabled the Central Bank to remit the foreign exchange obtained by the buyer to pay for the machinery and spare parts to the Appellant. Once the clean report of findings was issued by SGS, the Respondent was entitled to the commission. I therefore hold the view that Exhibit $\mathrm{F}$ is an on-demand bond and the Respondent was right to sue on it.

In our view, the above analysis is seriously misconceived. As earlier stated, an on-demand bond is a primary liability obligation, which arises from a surety's unconditional promise to pay, on demand, a stated sum to a beneficiary. Turning to the wordings of Welco's Customs Declaration Bond, it would be seen that Welco merely stated that: 'a commission of 4.4 per cent is recognized, calculated on the F.O.B. price for the amount of US $\$ 500,000$ to the company J. I. Nwanyanwu and Sons.' In our respectful opinion, whilst it is arguable that, by this declaration, Welco recognized that a commission is due to the Plaintiff; we are of the view, with the greatest respect to the Court of Appeal, that Welco's declaration is not, by any stretch, a primary obligation that engages an unconditional payment liability, upon demand.

\section{THE CASE FOR A CONSISTENT APPLICATION OF THE ANALYTICAL APPROACH}

A commentator has observed that guarantees are taken to provide a

40 Phillip Wood, Law and Practice of International Law: Comparative Law of Security and Guarantees (Oxford, 1995) 313. 
second pocket to pay if the first should be empty. ${ }^{40}$ In our view, a demand guarantee goes a step better: it ensures the availability of a rich pocket that cannot be bogged down with dilatory objections to payment. Observably, to achieve this ideal in Nigeria, the law relating to the construction and enforcement of demand guarantees must be clear and consistently applied. Currently, this is not the case.

There are several reasons why the Nigerian law relating to demand guarantees is hazy. First, there is the perplexing failure of the courts to recognize the crucial distinction between a true guarantee and a demand guarantee. In many instances (discussed above), the courts adopted a blanket approach of requiring proof of the principal's default in the underlying contract to the construction of all forms of guarantee undertakings. This approach has the unfortunate effect of stifling the growth of the legal principles that undergird demand guarantee contracts. Perhaps, the legal doctrine of stare decisis is to blame for this state of affair.

Traditionally, Nigerian courts prefer to follow well-tread (albeit erroneous) paths, and are overly cautious of developing new principles that maybe seen as being subversive of the established order. For example, in the Dragetanos case, after the Court of Appeal had, rightly, rejected the contractor's argument that the APG at issue was a contract of guarantee, wherein proof of default is a condition precedent to the bank's liability on the APG; the court somehow felt obliged to cite the Supreme Court's views in Fortune Bank v. Pegasus, which resulted in a contrary dicta that the obligations of the guarantor arise only when the principal has defaulted in his obligations to the creditor. Inevitably, the court handed down a muddled and contradictory judgement. ${ }^{41}$ In our view, law is a living concept, and judges should be courageous to throw off shackles of bad law wherever it manifests, moreso that surety contracts are flexible commercial instruments, which evolved in response to market needs.

Second, while it is true that legal principles are not formulated in vacuum, and that it is the complexities and novelty of disputes that are submitted for judicial resolution that affords an opportunity for development of the law; it is observed that even where the opportunity

41 For a detailed analysis of this decision, see Kolawole Mayomi, 'Dragetanos (Nig.) Ltd v. Fab-Madis Ventures Ltd: A Missed Opportunity to Develop the Law relating to Advance Payment Guarantees in Nigeria' (2015) 3(2) Appellate Review. 
arises, the Nigerian courts often appeared to be more interested in discussing procedural points, than in developing substantive principles of law that would be an invaluable guide to the men of commerce on how to conduct their business. Again, in the Dragetanos case, it will be seen that the court bypassed a rare opportunity to develop the law relating to Advance Payment Guarantees in Nigeriain its undue attention, for the bulk of its judgement, to the issue of the joinder of the bank to the contractor's counter-claim.

Furthermore, in many other cases, the courts seemed to have a proclivity to reproducing counsel's arguments as the bulk of their judgments, instead of focusing on the task of construction of the surety's contractual obligations. This approach may be contrasted with the approach of the English Court of Appeal in Wuhan Guoyu Logistics v. Emporiki Bank, ${ }^{42}$ where that court dealt with complex issues arising from the construction and enforcement of an Advance Payment Guarantee in a concise judgment of less than 11 pages. The court described the 20-page judgment of the trial court ${ }^{43}$ as 'an exhausting document', and observed that 'something has surely gone wrong if this comparatively simple question of construction requires such lengthy consideration... the commercial community deserves better than this, if better can be done'. ${ }^{44}$

Thirdly, the broad problem of Nigeria's loose appellate system is a contributory factor to the lack of development of substantive legal principles in the field of demand guarantees. A good example is the African Development Insurance Corporation case, where the Respondent sought to enforce a Performance Bond given by a contractor who had failed to deliver on a contractual obligation. Unfortunately, the case got bogged down with threshold jurisdiction issues and the appeal to the Supreme Court merely settled (about eight years after filing the suit) the question of the appropriate forum, and did not decide substantive issues relating to enforcement of the Bond.

Drawing the threads of the argument together, there is a compelling need for Nigerian courts to adopt an analytical approach of making a proper distinction between a true guarantee contract and a demand guarantee in the construction of surety contracts. This approach will,

42 [2012] EWCA Civ. 1629.

43 2012] EWHC 1715 Comm.

44 Wuhan Guoyu Logistics (n 42) [22]. 
in our view, bring into full focus the commercial essence of demand guarantee contracts: 'pay now, argue later'. ${ }^{45}$ In other words, a demand guarantee ensures the availability of funds for the timely completion of the underlying contract, as a guarantor who has promised to make payment, on demand, of a stated sum upon demand to cover the event of default will be held to his bargain, and would not be allowed to subject the beneficiary to a prolonged judicial resolution of a dispute on who is at fault.

This rule was applied in the recent English case of Team Telecom International Ltd $v$. Hutchinson $3 G,{ }^{46}$ where A contracted to supply B with a software which would monitor and manage B's mobile phone network, and a demand guarantee was provided by a bank to secure A's obligations under the contract. B made a call on the guarantee following an allegation that A was in breach. The grounds relied upon by the bank in refusing to pay were varied, and ranged from an allegation that the call was made in bad faith, to B's failure to meet the formalities of the demand. The court held that it was unable to summarily decide the parties' contentions because the factual and technical issues were quite complicated and could only be properly determined at a full trial. The court upheld B's demand, on the ground that since C's undertaking was a demand guarantee, it would be contrary to the presumed intention of the parties to allow the bank to refuse to pay until its liability was determined at trial.

Secondly, an analytical construction of demand guarantee obligations will determine the important issue of the standard of proof in enforcing the surety's obligations. The standard of proof in enforcing a demand guarantee contract is low: once the beneficiary makes a contractually-compliant demand on the guarantee, the contract must be enforced regardless of the merits of the call, except where the demand is manifestly fraudulent.

The situation is different in a true guarantee contract where the beneficiary bears a higher evidentiary burden of establishing the principal's default in the underlying contract before the surety's payment obligation may be enforced. In our view, the Nigerian court's blanket approach to the construction of all surety obligations as a true guarantee has the effect, particularly in the context of demand guarantees, of

45 McMeel (n 11).

46 [2003] EWHC 762 (TCC). 
making the beneficiary be a ran unnecessary evidentiary burden of establishing the principal's default in the underlying contract. This problem with this approach is clearly appreciated in a large construction project or international sale contract where milestone payments are required to enable timeous delivery of the contract. Where the principal disputes that a milestone payment is due, and the beneficiary is required to firstly establish default in the underlying contract before it can call upon the surety to make payment, the attention of the contracting parties would be taken up with a contest over who is at fault before the parties can move to the next stage of the contract, and the timeessence of the contract will be lost.

Thirdly, a consistent application of the analytical approach to the construction of demand guarantee undertakings will send positive vibes to the global financial market that the Nigerian courts are willing to take a commercial approach that recognizes the dynamics of commercial obligations. This development will help to instil confidence in financial market operators to submit disputes relating to other specialized financial instruments like swaps, derivatives, etc. to Nigerian law. Although these instruments are now widely used in the Nigerian financial system; in practice, the dispute resolution clauses in these instruments almost always defer to the jurisdiction of English courts, such that to date; there is no reported Nigerian judicial pronouncement on these important contractual species.

In recommending an analytical approach to the construction of demand guarantees, we are not unmindful of the attendant danger of fraud. ${ }^{47}$ Obviously, if a demand guarantee may be readily turned into money, unscrupulous beneficiaries would make unjustified demands for payment where the risk that is covered by the demand guarantee has not yet materialized. Indeed, in some of the reviewed cases, it will appear that some judges were probably influenced by a subconscious concern on fraud, going by their hesitation to declare the surety's obligations as enforceable upon the beneficiary's mere demand. These

47 Michelle Kelly-Louw, 'International Measures to Prohibit Fraudulent Calls on Demand Guarantees and Standby Letters of Credit' (2010) 1(1) Geo Mason Journal of Int'l Comm. Law 74. 
fears are probably justified. As at today, there is no general body of rules in Nigeria which addresses the problem of abusive calls on demand guarantee contracts. ${ }^{48}$

Accordingly, therefore, it is necessary to have a statutory intervention to deal with the gamut of issues that arise from the proper construction and enforcement of demand guarantees; as well as to set definitive standards of conduct that may constitute an abusive call on a demand guarantee in Nigeria. In clearly defined situations where fraud is manifest, the surety may, perhaps, be statutorily empowered to demand for proof of default under the underlying contract. At any event, we find it unsatisfactory that, in the present age where demand guarantees are routinely tendered in the global market for goods and services, the question of how the local Nigerian court will approach the construction and enforcement of a demand guarantee remains opaque. ${ }^{49}$ From this perspective alone, it is clear that statutory intervention is urgent and needful.

Considering the complex and oftenlong-drawn process of law making, we propose the convenient option of Nigeria's immediate ascension to, and domestication of the United Nations Convention on Independent Guarantees and Stand-by Letters of Credit 1995. ${ }^{50}$ Indeed, the Explanatory Notes to the Convention provide the following compelling reasons:

48 Although the ICC Uniform Rules on Demand Guarantees (URDG 758) makes a commendable attempt to deal with the problem of abusive calls, it would be seen that this instrument is not of public application; as it is a standard-term contract rules which only apply where parties have chosen to incorporate them into their contract.

49 Kelly-Louw (n 47) 95-96 notes that jurisdictions that do not fashion efficient rules, procedurally and otherwise, for resolving questions of fraud will soon find that credits and guarantees issued by their banks are not acceptable in the world markets.

50 The United Nations Convention on Independent Guarantees and Stand-by Letters of Credit was prepared by the United Nations Commission on International Trade Law (UNCITRAL), and was adopted and opened for signature by the UN General Assembly by its resolution 50/48 of 11 December 1995. As of 1 July 2015, eight nations have ratified or acceded to the Convention: Belarus, Ecuador, El-Salvador, Gabon, Kuwait, Liberia, Panama and Tunisia. The United States of America has signed the Convention but has not yet ratified it or acceded to it. See the United Nations Treaty Status Database, Chapter X § 15 $<$ https://treaties.un.org/pages/ViewDetails.aspx?src=TREATY\&mtdsg_no $=\mathrm{X}$ $15 \&$ chapter $=10 \&$ lang $=$ en $>$ accessed 20 October 2016. 
3. Independent undertakings covered by the Convention are basic tools of international commerce. They are used in a variety of situations... Yet familiarity with the instrument [s] covered by the Convention is not universal; there is an absence of legislative provisions dealing with them... and important questions confronting users, practitioners and courts in the daily life of these instruments are beyond the power of the parties to settle contractually.

45. A main purpose of the Convention is to establish greater uniformity internationally in the manner in which guarantor/issuers and courts respond to allegations of fraud or abuse in demands for payment under independent guarantees and stand-by letters of credit. That has been a particularly troublesome and disruptive area in practice because allegations of fraud have a tendency to arise when there is a dispute as to the performance of an underlying contractual obligation.

46. The Convention helps to ameliorate the problem by providing an internationally agreed general definition of the types of situations in which an exception to the obligation to pay against a facially compliant demand would be justified.

In our view, considering the Convention's above objectives, vis-avia our previous discussions on the problems that generally surrounds the Nigerian law relating to demand guarantees, the domestication of the Convention in Nigeria would go a long way in bringing clarity to the construction and enforcement of demand guarantee contracts.

\section{CONCLUSION}

The law relating to demand Guarantees in Nigeria has stagnated, if not regressed, since the African Insurance Development Corp case. The major reason for this stagnation is because the Nigerian courts, in the majority of the cases before them, failed to make a proper distinction between a true guarantee and a demand guarantee. Aside stultifying the growth of the law, this blanket approach is retrogressive as it (a) fails to reflect the true intent of the contracting parties properly, and (b) defeats the commercial purpose that requires the tender of a demand guarantee.

Accordingly, Nigerian courts should, as a matter of necessity, adopt the analytical approach whereby the dichotomy between an indemnity 
contract and a true guarantee is observed, and the surety's liability turns upon the proper construction of the surety's contractual obligations. Where a surety undertaking is classified as a demand guarantee, the summary payment obligations that are attendant upon this class of surety undertaking should naturally follow. This approach accords with best global practices and would ensure that Nigerian decisions are respected and enforced among the comity of nations. ${ }^{51}$

Statutory intervention would be an effective way of reversing the present regressive approach to the construction of demand guarantees in Nigeria, and enthroning the analytical approach. Moreover, considering the liquid nature of demand guarantees and the danger of fraudulent calls thereon, such statutory intervention will set a definite standard of the conduct that constitutes an abusive call on a demand guarantee, as well as to prescribe clear instances in which proof of default under an underlying contract may actually be required under a demand guarantee.

51 It is instructive to note the case of Power Curber International v. National Bank of Kuwait [1981] 1 WLR 1233, a Kuwaiti Court ordered that an English bank should not honour a call on a performance bond on the grounds that there was no proof of default in the underlying contract. The English Court of Appeal discountenanced this order. Griffiths LJ who delivered the judgement of the Court said: '... whenever possible this court will in the interests of comity seek to recognise and uphold the order of a friendly state. But, unhappily in this case, the approach of the Kuwaiti court appears to be so out of step with that of our own courts and the courts of other trading nations that I fear that we cannot recognise it. The choice lies between upholding the worldwide practices of international commerce or the order of the Kuwaiti courts. I choose the first option.' 